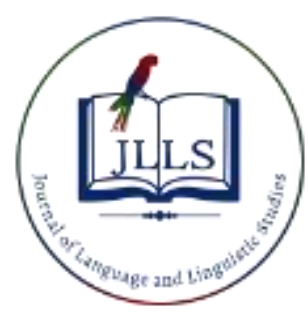

Available online at www.jlls.org

JOURNAL OF LANGUAGE

AND LINGUISTIC STUDIES

ISSN: $1305-578 \mathrm{X}$

Journal of Language and Linguistic Studies, 16(2), 959-977; 2020

\title{
The investigation into prospective teachers' Turkish metalinguistic awareness
}

\author{
İzzet Şeref a 1 (iD), Behice Varışoğlu b (iD) \\ ${ }^{a}$ Tokat Gaziosmanpaşa University, Tokat, Turkey \\ ${ }^{b}$ Tokat Gaziosmanpaşa University, Tokat, Turkey
}

\section{APA Citation:}

Şeref, İ. \& Varışoğlu, B. (2020). The investigation into prospective teachers' Turkish metalinguistic awareness. Journal of Language and Linguistic Studies, 16(2), 959-977.

Submission Date:18/12/2019

Acceptance Date:03/05/2020

\begin{abstract}
Language awareness is the totality of conscious efforts to know and practice the language. As to the metalinguistic awareness, it refers to the discovery of the social, cultural, historical and ideological aspects of language as a whole, as well as knowledge of the language and ability to use it. The current study aims to investigate native Turkish speakers' metalinguistic awareness who study at English Language Teaching, German Language Teaching, Turkish Language Teaching, and Turkish Literature departments according to their genders and departments. The study uses descriptive survey design, which is a quantitative approach. The population of the study consists of students who study at English Language Teaching, German Language Teaching, Turkish Language Teaching and Turkish Literature departments in Ataturk University Kazım Karabekir Faculty of Education. As to the sample, it consists of final year students chosen with purposive sampling technique $(\mathrm{N}=164)$. The data were collected via Turkish Metalinguistic Awareness Scale, developed by B. Varisoglu (2018). To analyze the data, descriptive analysis techniques were used. As a result, it was found out that prospective teachers have a higher level of linguistic awareness in Turkish, it was also seen that their lowest awareness is in morphological awareness sub-dimension and highest awareness is in the cultural awareness sub-dimension. It is also seen that there is significant difference in favor of female prospective teachers according to the gender variable, but the department variable does not have a significant effect on their Turkish metalinguistic awareness.
\end{abstract}

(C) 2020 JLLS and the Authors - Published by JLLS.

Keywords: language; language education; language awareness; Turkish metalinguistic awareness; prospective teachers

\section{Introduction}

Language awareness was first introduced to the world of science with Eric Hawkins's Awareness of Language: An Introduction, which then became widespread with the continued publication of Language Awareness and is a field of research now. The term was initially used to increase the language skills of school-age people and to reorganize education by taking into account the problems experienced by those who are inadequate in mother tongue skills and metalinguistic knowledge.

\footnotetext{
${ }^{1}$ Corresponding author. Tel.: +90-543-547-4245

E-mail address: izzet.seref@gop.edu.tr
} 
As the term language awareness began to be mentioned in the studies of linguistics, cognitive psychology, mother tongue, and foreign language teaching, language planning, functional literacy, and learning psychology, it has become a subject of detailed studies as a new research area. Especially in the studies related to explicit knowledge and implicit knowledge transfer, language awareness is referred to and its functionality in one's language use is discussed (Buyukkantarcioglu, 2006, p. 104).

Language awareness is a mental quality that enables people to gain insight by drawing attention to how users produce the language and how it works. It is also a pedagogical approach that aims to help students gain such insights (Bolitho, Carter, Hughes, Ivanic, Masuhara \& Tomlinson, 2003). During the process of language acquisition, language awareness needs to be developed to ensure that children have a healthy spirit of inquiry. Again, in this process, children must have different and several views about language in terms of developing language awareness.

According to Van Lier (1991, p. 347), language awareness, when regarded as an approach in language teaching-learning process, advocates an understanding that rejects to teach grammar deductively, that is, the transfer of knowledge and rules about a language to learners as they are. Language awareness is not taught directly by teachers or textbooks but developed intuitively and internally by the learner gradually. Besides, language awareness contributes to the training of careful, positive and curious students through an attempt to discover and express language during language use.

Using the language consciously is the clearest indication of respect and devotion to the language and culture. Language motivation, language attitude, and language awareness are important factors that affect one's choice of language and the use of it. In this context, language awareness is defined as the specific knowledge that one has about the language he speaks, his conscious perception and sensitivity towards language teaching-learning and language use in general, and his conscious attention on the relationship between culture and language (Byram, 2012).

Language awareness is "an important factor that contributes to language unity and facilitates reconciliation and agreement among the people who speak that language" (B. Varisoglu, 2018). Thanks to people's awareness of language, the sense of ownership of language and understanding of using it develop. Language awareness is also the totality of one's language sensitivity and perception.

Language awareness is "the conscious sensitivity and awareness that the individual develops for the characteristics of language and its functions in life" (Little, 1997, p. 33). At the same time, it is also defined as the observable and unobservable side of one's language ability, which is thought to be innate, through its use. When viewed from this respect, language ability and language acquisition overlap, and a distinction between language awareness and linguistic awareness is drawn. Language awareness is more related to applied linguistic theory and pedagogy, while linguistic awareness is related to the automatic control of repeated linguistic practices through mind control and the transformation of this knowledge and skills into life practices and having a meaning and function again in life practices (Buyukkantarcioglu, 2006, p. 105).

As for metalinguistic awareness, it refers to the situation where one thinks about the language he speaks and regulates the structural features of the language consciously (Batur \& Beyret, 2015). It is also the totality of one's sense, thought, ideology, judgment, and knowledge, as well as physical and mental reactions about the language he speaks. It is considered to be a general concept that includes basic language awareness related to language units such as voice, word, sentence, and meaning and it is also related to many skills including language and communication dimension.

\subsection{Related research}

When the literature is examined, it is seen that it focuses on issues such as language awareness, linguistic awareness, metalinguistic awareness, critical language awareness, cultural awareness, 
pragmatical awareness, and teacher language awareness. Along with these, the issues on sub-dimensions of language such as phonological awareness, morphological awareness, syntactic awareness, and semantic awareness are also investigated in the literature.

Some of these studies can be illustrated as follows:

Metalinguistic Awareness (Tucker, 1976; Johns, 1979; Hamilton \& Barton, 1980; Bednar, 1990; Cazden, 1991; Andrews, 1997; Jessner, 1999; Acarlar, Ege \& Turan, 2002; Zipke, 2008; Alderson \& Hudson, 2012; Jackson, 2014).

Language Awareness (Wright \& Bolitho, 1993; Andrews, 2001; Bolitho, Carter, Hughes, Ivanic, Masuhara \& Tomlinson, 2003; Carter, 2003; Kaya, 2010; Ellis, 2012; Mok, 2013; Berry, 2014; Onan \& Ozcomak, 2014; White \& Kennedy, 2014; Kissling \& O’Donnell, 2015; Cin Seker, 2019).

Critical Language Awareness (Diniz Leal, 1998; Alim, 2005; Ali, 2011).

Teacher Language Awareness (Andrews, 2007; Harbon, 2007; Andrews, 2008).

Phonological Awareness (Akbey, 2016; Guldenoglu, Kargin \& Ergul, 2016; Emir, Girgin \& Karasu, 2015; Turan \& Akoglu, 2014; Akoglu \& Turan, 2012; Erdogan, 2011; Erkan Suel, 2011; Karaman ve Ustun, 2011; Turan \& Akoglu, 2011; Erdogan, 2009; Yucel, 2009; Turan \& Gul, 2008; Gokçe, 2006; Gul, 2006; Karaman, 2006; Anthony \& Francis, 2005; Gillon, 2005; Gillon, 2004; Gibbs, 2004; Mann \& Joy, 2003; Allor, 2002; Oktay \& Aktan, 2002; Aktan, 1996; Acarlar, 1995).

Morphological Awareness (Ke \& Xiao, 2015; Zhang \& Li, 2016; Cin Seker, 2018).

Syntactic Awareness (Smith, 2008).

Semantic Awareness (Zheng, 2014).

Cultural Awareness (Tomlinson \& Masuhara, 2004; Byram, 2012; Iscan, Karagöz \& Konyar, 2017).

The most researched topic in the literature is phonological awareness. Phonological awareness refers to the awareness of the relationship between the letters in the alphabet and the sounds of speech. It deals with the words in smaller units such as sound, syllable, and rhyme (Yucel, 2009, p. 13). Morphological awareness is based on having the necessary information about the word structure of spoken language, recognizing the root, stem, and suffixes of the word, deriving words, knowing, understanding and transferring the derivation features of the language (Karadag \& Kurudayioglu, 2010). The type of awareness that requires knowing and applying the structural, functional and semantic features of all elements constituting the sentence is called syntactic awareness (Batur \& Beyret, 2015). Semantic awareness, on the other hand, is the process of knowing about, comprehending and using rhetorical devices, as well as understanding the content of words and forms such as idioms, phrases, and proverbs.

Broadly speaking, language awareness is a factor that significantly increases people's level of achievement in the process of learning and teaching a language. So, it is important to determine prospective teachers' language awareness who will be native or foreign language teachers in the future and to make arrangements in the education process within the framework of the findings. This study is important in terms of revealing metalinguistic awareness of prospective teachers and offering suggestions to field experts in this field.

This study aims to investigate native Turkish speakers' metalinguistic awareness who study at English Language Teaching, German Language Teaching, Turkish Language Teaching, and Turkish Literature departments and take various language-oriented courses in these departments. By this purpose, it answers the following questions:

1. At what level is prospective teachers' metalinguistic awareness who study at English, German, Turkish Language teaching and Turkish Literature teaching departments? 
2. Does prospective teachers' metalinguistic awareness who study at English, German, Turkish Language teaching and Turkish Literature teaching departments differ according to their genders?

Does prospective teachers' metalinguistic awareness who study at English, German, Turkish Language teaching and Turkish Literature teaching departments differ according to their departments?

\section{Method}

\subsection{Research design}

This study follows the principles of quantitative research and uses and descriptive survey model. In this model, the characteristics of a specific group are determined and then the data are obtained from the sample at once (Buyukozturk, Kilic Cakmak, Akgun, Karadeniz \& Demirel, 2014). This design was preferred because it is a useful model for collecting data from large groups.

\subsection{The population and the sample}

The population of the study consists of students who study at English Language Teaching, German Language Teaching, Turkish Language Teaching and Turkish Literature departments in Ataturk University Kazım Karabekir Faculty of Education, while the sample consists of final year students chosen with purposive sampling technique. 123 of the volunteer participants in the sample are female students while the rest 41 are male students.

\subsection{Data collection tool}

The data of the study were collected via Turkish Metalinguistic Awareness Scale developed by B. Varisoglu (2018). The scale was designed as a 5-point Likert scale. The scale consists of six subdimensions and a total of 41 items. B. Varisoglu (2018) states that the Cronbach's Alpha value of the scale was calculated as 0.871 for the overall scale and the reliability coefficient of the sub-dimensions was calculated 0.874 for phonological awareness, 0.869 for morphological awareness, 0.872 for semantic awareness, 0.871 for syntactic awareness, 0.876 for communicative awareness and 0.870 for cultural awareness. In this study, the overall reliability coefficient of the scale was calculated as 0.94 . The results of both studies seem to be consistent with each other in terms of the reliability coefficient. The fact that the calculated alpha value is so high shows that the data collected in this study were collected with a very reliable tool.

\subsection{Data analysis}

In this study, particularly along with arithmetic mean, t-test and ANOVA test were also used to reveal the relationship between the gender and department variables with scale items, which are descriptive analysis techniques. The data were evaluated according to $95 \%$ confidence interval.

\section{Results}

Under this heading are the data related to prospective teachers' Turkish metalinguistic awareness, the average scores obtained from the scale according to the departments (Table 1), the results of the $t$ test scores obtained from the factors in the scale according to the gender variable (Table 2), the results of variance analysis according to department variable (Table 4). 
Table 1. Prospective teachers' average scores in Turkish Metalinguistic Awareness Scale according to their departments

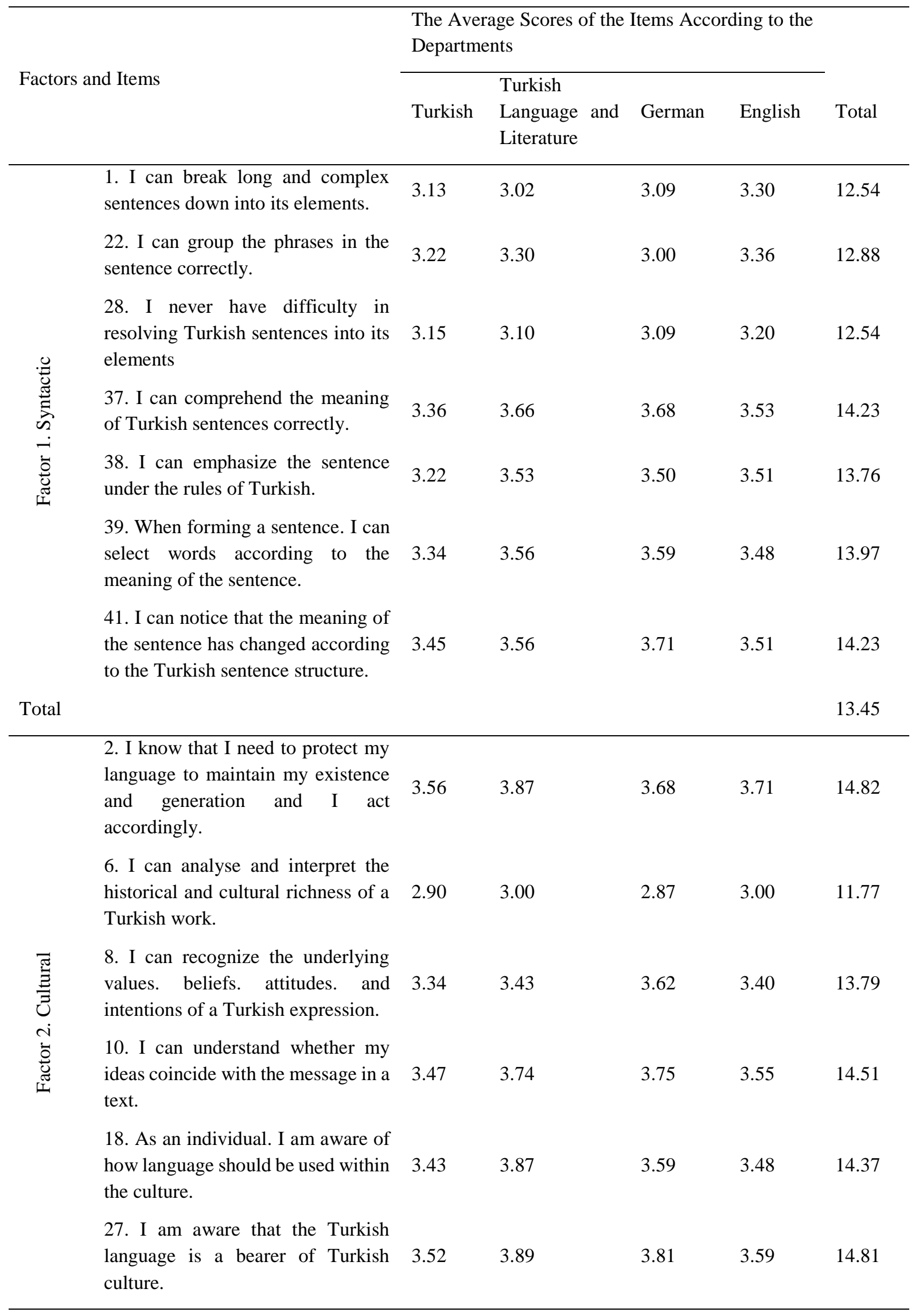




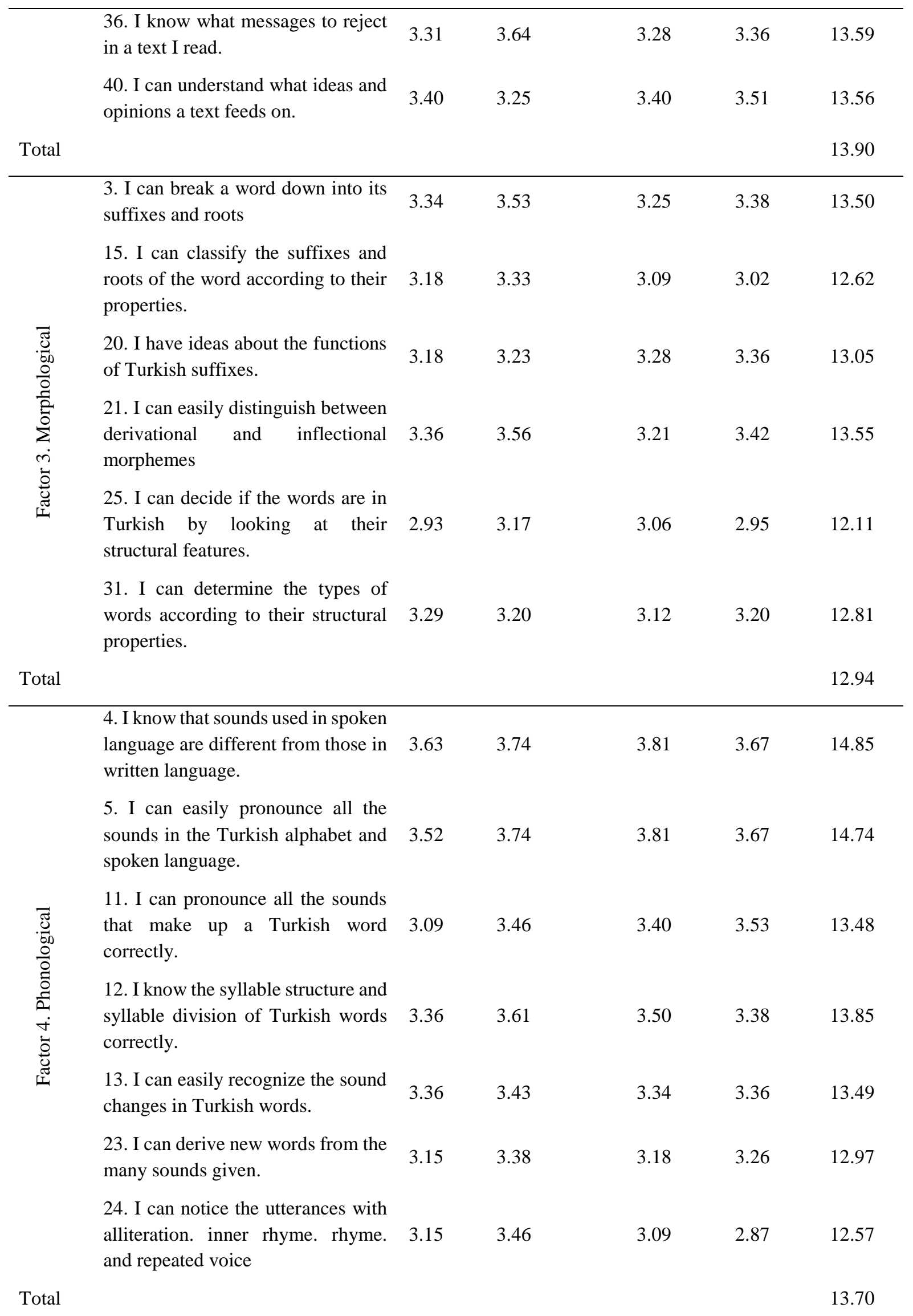




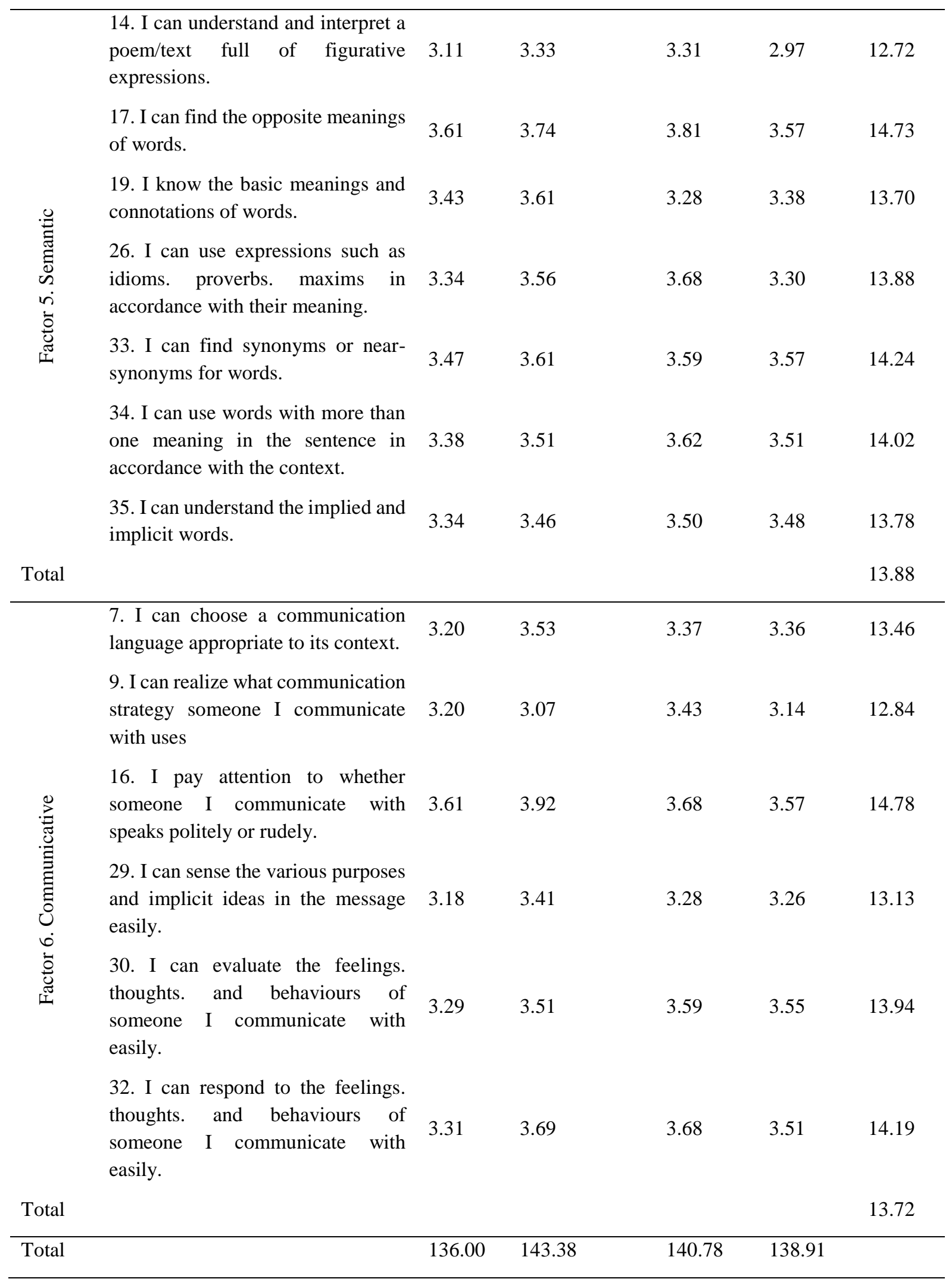

Table 1 presents the prospective teachers' average scores in Turkish Metalinguistic Awareness Scale according to their departments. According to this, it is seen that prospective teachers studying at Turkish Language and Literature department have higher Turkish metalinguistic awareness than others $(\bar{X}=143.38)$. On the other hand, when this table is evaluated holistically, it is seen that the prospective 
teachers' Turkish metalinguistic awareness is above a certain average. This is more evident considering the prospective teachers' average scores who study at Turkish Language teaching department. Even they have the lowest average; it makes up $82 \%$ of the total score. It is also determined that their lowest awareness is in factor 3 (morphological awareness) $(\bar{X}=12.94)$, and the highest awareness in factor 2 (Cultural Awareness) $(\bar{X}=13.90)$. Also, it is seen their lowest awareness belongs to the item six (I can analyze and interpret the historical and cultural richness of a Turkish work.) $(\overline{\mathrm{X}}=11.77)$, and highest awareness to item four (I know that sounds used in spoken language are different from those in written language.) $(\overline{\mathrm{X}}=14.85)$. To evaluate the data from a different perspective, $\mathrm{t}$-test was used to determine the relationship between prospective teachers' scores and genders and these data are presented in Table 2 .

Table 2. The t-test results of the prospective teachers' scores in Turkish metalinguistic awareness scale according to gender variable

\begin{tabular}{|c|c|c|c|c|c|c|}
\hline Factor & Gender & $\mathrm{N}$ & $\bar{x}$ & ss & $\mathrm{t}$ & $\mathrm{p}<0.05$ \\
\hline \multirow{2}{*}{$\begin{array}{l}\text { Factor } \\
\text { Syntactic }\end{array}$} & Female & 123 & 23.95 & 2.95 & \multirow{2}{*}{-2.539} & \multirow{2}{*}{.014} \\
\hline & Male & 41 & 22.39 & 3.56 & & \\
\hline \multirow{2}{*}{$\begin{array}{l}\text { Factor } \\
\text { Cultural }\end{array}$} & Female & 123 & 28.07 & 2.97 & \multirow{2}{*}{-2.024} & \multirow{2}{*}{.045} \\
\hline & Male & 41 & 26.95 & 3.35 & & \\
\hline \multirow{2}{*}{$\begin{array}{l}\text { Factor } 3 . \\
\text { Morphological }\end{array}$} & Female & 123 & 19.86 & 2.75 & \multirow{2}{*}{-3.239} & \multirow{2}{*}{.001} \\
\hline & Male & 41 & 18.19 & 3.14 & & \\
\hline \multirow{2}{*}{$\begin{array}{l}\text { Factor } 4 . \\
\text { Phonological }\end{array}$} & Female & 123 & 24.21 & 2.74 & \multirow{2}{*}{-1.861} & \multirow{2}{*}{.065} \\
\hline & Male & 41 & 23.24 & 3.35 & & \\
\hline \multirow{2}{*}{$\begin{array}{l}\text { Factor } \\
\text { Semantic }\end{array}$} & Female & 123 & 24.46 & 3.11 & \multirow{2}{*}{-1.846} & \multirow{2}{*}{.067} \\
\hline & Male & 41 & 23.41 & 3.27 & & \\
\hline \multirow{2}{*}{$\begin{array}{l}\text { Factor } 6 . \\
\text { Communicative }\end{array}$} & Female & 123 & 20.87 & 2.47 & \multirow{2}{*}{-2.442} & \multirow{2}{*}{.018} \\
\hline & Male & 41 & 19.58 & 3.07 & & \\
\hline \multirow{2}{*}{ Total } & Female & 123 & 141.48 & 14.54 & \multirow{2}{*}{-2.798} & \multirow{2}{*}{.006} \\
\hline & Male & 41 & 133.78 & 17.30 & & \\
\hline
\end{tabular}

Table 2 presents the data showing how prospective teachers' scores in Turkish Metalinguistic Awareness Scale differ according to the gender variable. Remarkably, there is significant difference in the syntactic, cultural, morphological and communicative factors of the scale in favor of female prospective teachers. Although the female prospective teachers' average scores in phonological and semantic factors are higher than the males', these data are not statistically significant. Besides, there is significant difference in favor of girls according to the total scores obtained from the scale $(\bar{X}=141,48$, $\mathrm{p}=, 006$ ). Table 3 presents the data showing the prospective teachers' scores according to the department variable. 
Table 3. The data showing the prospective teachers' scores in Turkish metalinguistic awareness scale according to the department variable

\begin{tabular}{|c|c|c|c|c|c|c|}
\hline \multirow[b]{2}{*}{ Factors } & \multirow[b]{2}{*}{ Department } & \multirow[b]{2}{*}{$\mathrm{N}$} & \multirow[b]{2}{*}{$\bar{x}$} & \multirow[b]{2}{*}{ ss } & \multicolumn{2}{|c|}{$95 \%$ Confidence Interval } \\
\hline & & & & & $\begin{array}{l}\text { Lower } \\
\text { limit }\end{array}$ & Upper limit \\
\hline \multirow{4}{*}{ Factor 1. Syntactic } & $\begin{array}{l}\text { Turkish Language } \\
\text { Teaching }\end{array}$ & 44 & 22.90 & 3.42 & 21.86 & 23.95 \\
\hline & $\begin{array}{l}\text { Turkish Literature } \\
\text { Teaching }\end{array}$ & 39 & 23.76 & 2.99 & 22.79 & 24.74 \\
\hline & $\begin{array}{l}\text { German Language } \\
\text { Teaching }\end{array}$ & 32 & 23.68 & 2.92 & 22.63 & 24.74 \\
\hline & $\begin{array}{l}\text { English Language } \\
\text { Teaching }\end{array}$ & 49 & 23.91 & 3.27 & 22.97 & 24.85 \\
\hline \multirow{4}{*}{ Factor 2. Cultural } & $\begin{array}{l}\text { Turkish Language } \\
\text { Teaching }\end{array}$ & 44 & 26.97 & 3.54 & 25.89 & 28.05 \\
\hline & $\begin{array}{l}\text { Turkish Literature } \\
\text { Teaching }\end{array}$ & 39 & 28.71 & 1.98 & 28.07 & 29.36 \\
\hline & $\begin{array}{l}\text { German Language } \\
\text { Teaching }\end{array}$ & 32 & 28.03 & 3.05 & 26.93 & 29.13 \\
\hline & $\begin{array}{l}\text { English Language } \\
\text { Teaching }\end{array}$ & 49 & 27.63 & 3.30 & 26.68 & 28.58 \\
\hline \multirow{4}{*}{$\begin{array}{l}\text { Factor } 3 . \\
\text { Morphological }\end{array}$} & $\begin{array}{l}\text { Turkish Language } \\
\text { Teaching }\end{array}$ & 44 & 19.29 & 3.15 & 18.33 & 20.25 \\
\hline & $\begin{array}{l}\text { Turkish Literature } \\
\text { Teaching }\end{array}$ & 39 & 20.05 & 2.48 & 19.24 & 20.85 \\
\hline & $\begin{array}{l}\text { German Language } \\
\text { Teaching }\end{array}$ & 32 & 19.03 & 3.25 & 17.85 & 20.20 \\
\hline & $\begin{array}{l}\text { English Language } \\
\text { Teaching }\end{array}$ & 49 & 19.36 & 2.86 & 18.54 & 20.18 \\
\hline \multirow{4}{*}{$\begin{array}{l}\text { Factor } 4 . \\
\text { Phonological }\end{array}$} & $\begin{array}{l}\text { Turkish Language } \\
\text { Teaching }\end{array}$ & 44 & 23.29 & 3.08 & 22.35 & 24.23 \\
\hline & $\begin{array}{l}\text { Turkish Literature } \\
\text { Teaching }\end{array}$ & 39 & 24.84 & 2.21 & 24.12 & 25.56 \\
\hline & $\begin{array}{l}\text { German Language } \\
\text { Teaching }\end{array}$ & 32 & 24.15 & 3.22 & 22.99 & 25.31 \\
\hline & $\begin{array}{l}\text { English Language } \\
\text { Teaching }\end{array}$ & 49 & 23.77 & 2.98 & 22.91 & 24.63 \\
\hline \multirow[b]{2}{*}{ Factor 5. Semantic } & $\begin{array}{l}\text { Turkish Language } \\
\text { Teaching }\end{array}$ & 44 & 23.70 & 3.15 & 22.74 & 24.66 \\
\hline & $\begin{array}{l}\text { Turkish Literature } \\
\text { Teaching }\end{array}$ & 39 & 24.74 & 2.72 & 23.86 & 25.62 \\
\hline
\end{tabular}




\begin{tabular}{|c|c|c|c|c|c|c|c|}
\hline & & $\begin{array}{l}\text { German Language } \\
\text { Teaching }\end{array}$ & 32 & 24.81 & 3.29 & 23.62 & 26.00 \\
\hline & & $\begin{array}{l}\text { English Language } \\
\text { Teaching }\end{array}$ & 49 & 23.81 & 3.39 & 22.84 & 24.79 \\
\hline \multirow{4}{*}{$\begin{array}{l}\text { Factor } \\
\text { Communicative }\end{array}$} & \multirow{4}{*}{6.} & $\begin{array}{l}\text { Turkish Language } \\
\text { Teaching }\end{array}$ & 44 & 19.81 & 3.23 & 18.83 & 20.80 \\
\hline & & $\begin{array}{l}\text { Turkish Literature } \\
\text { Teaching }\end{array}$ & 39 & 21.15 & 1.92 & 20.52 & 21.77 \\
\hline & & $\begin{array}{l}\text { German Language } \\
\text { Teaching }\end{array}$ & 32 & 21.06 & 2.63 & 20.11 & 22.01 \\
\hline & & $\begin{array}{l}\text { English Language } \\
\text { Teaching }\end{array}$ & 49 & 20.40 & 2.58 & 19.66 & 21.15 \\
\hline \multirow{4}{*}{ Total } & & $\begin{array}{l}\text { Turkish Language } \\
\text { Teaching }\end{array}$ & 44 & 136.00 & 17.92 & 134.30 & 143.53 \\
\hline & & $\begin{array}{l}\text { Turkish Literature } \\
\text { Teaching }\end{array}$ & 39 & 143.38 & 11.63 & 139.61 & 147.15 \\
\hline & & $\begin{array}{l}\text { German Language } \\
\text { Teaching }\end{array}$ & 32 & 140.78 & 15.11 & 135.33 & 146.22 \\
\hline & & $\begin{array}{l}\text { English Language } \\
\text { Teaching }\end{array}$ & 49 & 138.91 & 16.06 & 134.30 & 143.53 \\
\hline
\end{tabular}

Table 3 presents the data showing the prospective teachers' scores according to the department variable. As is shown, the average score is $\mathbf{1 3 6 . 0 0}$ for prospective Turkish Language teachers, 143.38 for prospective Turkish Literature teachers, 140.78 for prospective German Language teachers and 138.91 for prospective English Language teachers. In other words, the highest average belongs to prospective Turkish Literature teachers, while the lowest is prospective Turkish Language teachers'. To see if there is significant difference in both sub-factors and all of the items according to the department variable, variance analysis was performed and the data obtained are presented in Table 4.

Table 4. The results of the analysis of variance of prospective teachers' scores from the factors in Turkish metalinguistic awareness scale according to department variable

\begin{tabular}{|c|c|c|c|c|c|c|c|}
\hline Factors & & $\begin{array}{ll}\text { Sources of } \\
\text { Variance }\end{array}$ & $\begin{array}{l}\text { Sum of } \\
\text { Squares }\end{array}$ & $\mathrm{Sd}$ & Mean squares & $\mathrm{F}$ & $\mathrm{p}$ \\
\hline \multirow{3}{*}{$\begin{array}{l}\text { Factor } \\
\text { Syntactic }\end{array}$} & \multirow{3}{*}{1.} & Intergroup & 27.154 & 3 & 9.051 & \multirow{3}{*}{.890} & \multirow{3}{*}{.448} \\
\hline & & $\begin{array}{l}\text { Within Group } \\
\text { (error) }\end{array}$ & 1627.108 & 160 & 10.169 & & \\
\hline & & Total & 1654.262 & 163 & & & \\
\hline \multirow{3}{*}{$\begin{array}{l}\text { Factor } \\
\text { Cultural }\end{array}$} & & Intergroup & 65.720 & 3 & 21.907 & \multirow{3}{*}{2.332} & \multirow{3}{*}{.076} \\
\hline & 2. & $\begin{array}{l}\text { Within Group } \\
\text { (error) }\end{array}$ & 1503.231 & 160 & 9.395 & & \\
\hline & & Total & 1568.951 & 163 & & & \\
\hline
\end{tabular}




\begin{tabular}{|c|c|c|c|c|c|c|}
\hline \multirow{3}{*}{$\begin{array}{l}\text { Factor } 3 . \\
\text { Morphological }\end{array}$} & Intergroup & 21.093 & 3 & 7.031 & \multirow{3}{*}{.813} & \multirow{3}{*}{.488} \\
\hline & $\begin{array}{l}\text { Within Group } \\
\text { (error) }\end{array}$ & 1383.413 & 160 & 8.646 & & \\
\hline & Total & 1404.506 & 163 & & & \\
\hline \multirow{3}{*}{$\begin{array}{l}\text { Factor } 4 . \\
\text { Phonological }\end{array}$} & Intergroup & 52.917 & 3 & 17.639 & \multirow{3}{*}{2.098} & \multirow{3}{*}{.103} \\
\hline & $\begin{array}{l}\text { Within Group } \\
\text { (error) }\end{array}$ & 1344.985 & 160 & 8.406 & & \\
\hline & Total & 1397.902 & 163 & & & \\
\hline \multirow{3}{*}{$\begin{array}{l}\text { Factor } \\
\text { Semantic }\end{array}$} & Intergroup & 41.54 & 3 & 13.848 & \multirow{3}{*}{1.384} & \multirow{3}{*}{.250} \\
\hline & $\begin{array}{l}\text { Within Group } \\
\text { (error) }\end{array}$ & 1600.817 & 160 & 10.005 & & \\
\hline & Total & 1642.360 & 163 & & & \\
\hline \multirow{3}{*}{$\begin{array}{l}\text { Factor } 6 . \\
\text { Communicative }\end{array}$} & Intergroup & 47.172 & 3 & 15.724 & \multirow{3}{*}{2.228} & \multirow{3}{*}{.087} \\
\hline & $\begin{array}{l}\text { Within Group } \\
\text { (error) }\end{array}$ & 1129.334 & 160 & 7.058 & & \\
\hline & Total & 1176.506 & 163 & & & \\
\hline \multirow{3}{*}{ Total } & Intergroup & 1196.017 & 3 & 398.672 & \multirow{3}{*}{1.660} & \multirow{3}{*}{.178} \\
\hline & $\begin{array}{l}\text { Within Group } \\
\text { (error) }\end{array}$ & 38420.373 & 160 & 240.127 & & \\
\hline & Total & 39616.390 & 163 & & & \\
\hline
\end{tabular}

According to the analysis of variance, there is no significant relationship between the scores obtained from the scale and the department variable in all sub-factors and the total score (Table 4). This result reveals that the prospective teachers' Turkish metalinguistic awareness does not differ according to their departments and it has similar averages. Although prospective Turkish Literature teachers' average score in factor 1 (syntactic awareness), factor 2 (cultural awareness), factor 3 (morphological awareness), factor 4 (phonological awareness) and factor 6 (communicative awareness) is higher than other prospective teachers', this is not statistically significant. In factor 5 (semantic awareness), the highest average belongs to prospective German Language teachers. However, this does not lead to a statistically significant result. When a general evaluation is carried out according to the department variable, it can be stated that the prospective teachers' metalinguistic awareness is above the average, but there is no significant difference between the departments in favor of any department.

\section{Discussion}

This study investigates prospective teachers' Turkish metalinguistic awareness who study at language education departments according to their genders and departments. The study is important in terms of reflecting prospective teachers' metalinguistic awareness. Since they are important partners of mother or foreign language teaching, determining their awareness may provide useful information about undergraduate programs, materials used in language classes, language policies and many others. So, it can be possible to determine what to do to be more successful in language teaching. 
Relying on the literature related to the importance and purpose of teaching grammar, Dolunay (2010) considers "grammar teaching as an area that can be used to help students acquire four basic language skills, not a prime target". In other words, teaching grammar should not aim to teach the rules of the language itself but to acquire the ability to use the language correctly and effectively. However, when the studies carried out on grammar teaching are examined, it is seen that "grammar studies focus just on terms and grammar rules are memorized" (Kilic \& Akcay, 2011); students memorize grammar rules during their learning experiences in primary education (Demir \& Yapici, 2007), and grammar is not taught consciously to students (Aytas \& Cecen, 2010). Language teachers have important responsibilities in overcoming these problems because they are the practitioners of teaching process. Many problems in language teaching process can be solved if teachers can help their students learn strategies, methods, and techniques to acquire language skills adequately during their undergraduate education. To do this, first of all, undergraduate programs should be reviewed and updated, after determining the problems in practices based on prospective teachers' opinions. For example, as in this study, prospective teachers' Turkish metalinguistic awareness can be revealed, since metalinguistic awareness is about recognizing, knowing the sub-dimensions of language as a system/arrangement and producing new texts. In a more holistic approach, language awareness is the ability to know the social life and thinking the style of the language community, the relationship between language and thought, bilingualism, children's language acquisition and the principles of polysemy (Karaagac, 2013, p. 841) in learning of language units and their functions. In concrete terms, separating the sentence into words, syllables, and phonemes, deciding whether the sentence is correct in terms of the components of the language, forming words by combining the sounds, finding rhyming words, figures of speech are some points related to metalinguistic awareness (Sayar \& Turan, 2012, p. 50)

In this study, which aims to determine prospective language teachers' Turkish metalinguistic awareness, it is seen that the prospective teachers have a higher level of Turkish metalinguistic awareness. However, it is determined that prospective Turkish Literature teachers have higher Turkish metalinguistic awareness than others. In a study by Karakas, Turkan \& Ozdemir (2013), it is stated that students at the faculty of education and faculty of letters have a higher level of language sensitivity. Based on this finding, it is possible to state that prospective teachers can use Turkish basic language skills consciously or have awareness in this direction. This thought can be explained in the light of studies in the literature. For example, According to Batur \& Beyret (2015), the writing skills of the students with metalinguistic awareness are developed accordingly. Based on the studies upon metalinguistic awareness in literature, Sayar \& Turan (2012) state that metalinguistic awareness has a predictive effect on one's reading development. The results of other studies also reveal that metalinguistic awareness has a significant effect on the acquisition of reading and writing skills (Erdogan, 2011; Yucel, 2009).

When the sub-dimensions of the scale are evaluated, it is seen that the prospective teachers' lowest awareness is in morphological awareness sub-dimension $(\bar{X}=12.94)$, and the highest awareness in the cultural awareness sub-dimension $(\bar{X}=13.90)$. However, there is no significant difference between these two results. In other words, prospective teachers' average scores are very close to each other. Nevertheless, the data obtained should be evaluated. The fact that prospective teachers have a lower level of morphological awareness than other awareness areas reveals that they do not consider themselves competent enough to use these functions in deriving new words, recognizing Turkish morphological properties and expressing themselves. Especially, the average of the item "I can decide if the words are in Turkish by looking at their structural features." $(\bar{X}=12.11)$ is thought-provoking. From this point of view, it is possible to say that the prospective teachers are not sensitive enough about the Turkish morphological features and as a result, they may have difficulty in deciding whether a word is Turkish or not. Similar expressions can also be put forward for the item "I can classify the suffixes 
and roots of the word according to their properties". This may be due to the fact that prospective teachers learned Turkish and its grammar in the context of rules, not functionally during their education life including undergraduate education. Borekci $(2009$, p. 3) states that the basic function of language in a teaching process is limited to communicating when the language is merely composed of rules, but he emphasizes that the basic function of a language is to establish a relationship between human and object and to transfer the real world to the fictional world by providing the formation of a cognitive activity. Similarly, Ekinci Celikpazu (2019) states that teaching the rules, not the functions of the language structures, may cause the students not to create language awareness and move away from the love of language. Therefore, first of all, a consistent process including knowledge, skills, and values needs to be followed to help students acquire listening/following, speaking, reading and writing skills as well as linguistic and cognitive skills, improve themselves personally and socially, communicate effectively, and have a habit of reading and writing in Turkish lovingly (The Ministry of National Education, 2018, p. 8).

When the items in the scale are examined one by one, it is seen that prospective teachers' lowest awareness $(\bar{X}=11.77)$; is in the item "I can analyze and interpret the historical and cultural richness of a Turkish work", while the highest $(\bar{X}=14.85)$ is in the item "I know that sounds used in spoken language are different from those in written language". The first situation suggests that prospective teachers' intertextual reading awareness is not sufficient, because, to make sense of a work in every aspect, it is necessary to explore the reference field of the work. When these connections cannot be established, the work is not fully understood. From a different perspective, it is possible to say prospective teachers have difficulty in understanding works in Ottoman Turkish. In parallel with this, a study by M.C. Varisoglu (2018) shows that prospective Turkish Literature teachers have difficulty in interpreting historical texts.

It is clear that gender makes an important statistical difference in prospective teachers' metalinguistic awareness. There is significant difference in favor of female prospective teachers in syntactic, cultural, morphological and communicative sun-dimensions of the scale. In phonological and semantic subdimensions, gender seems to make no significant difference.

Prospective teachers' Turkish metalinguistic awareness is investigated in terms of their departments, and the average score is 136.00 for prospective Turkish Language teachers, 143.38 for prospective Turkish Literature teachers, 140.78 for prospective German Language teachers and 138.91 for prospective English Language teachers. The highest average belongs to prospective Turkish Literature teachers, while the lowest is prospective Turkish Language teachers'. There is no statistically significant difference in overall scale and sub-dimensions according to the department variable. Although the average of prospective Turkish Literature teachers is higher than the average of prospective Turkish, German and English Language teachers, this case does not affect the results statistically.

Considering the results of the study, the following suggestions can be presented for scientists who will conduct studies in this field:

1. Prospective teachers' Turkish metalinguistic awareness can be determined according to different samples.

2. In addition to prospective teachers, secondary and high school students' metalinguistic awareness can be investigated.

3. Experimental studies can be conducted at any stage of education to reveal how metalinguistic awareness affects students' learning processes in what aspects.

4. This study shows that prospective teachers have a higher level of Turkish metalinguistic awareness. To determine whether this result is reflected in prospective teachers' language skills, studies with different patterns can be conducted. 
This study is limited to 123 female and 41 male prospective teachers' views in B. Varioglu's "Turkish Metalinguistic Awareness Scale" (2018), studying at English Language Teaching, German Language Teaching, Turkish Language Teaching and Turkish Literature departments in Ataturk University Kazım Karabekir Faculty of Education.

\section{Ethics Committee Approval}

The author confirms that ethics committee approval was obtained from Tokat Gaziosmanpaşa University Social and Human Sciences Ethical Committee (Approval Date and Number: 21/05/2020, 07.06).

\section{References}

Acarlar, F. (1995). Türkçe kazanımında kullanılan fonolojik süreçlerin incelenmesi ve fonolojik bozukluğu olan çocuklardaki süreçlerle karşılaştırılması (Unpublished doctoral dissertation). Hacettepe University, Ankara.

Acarlar, F., Ege, P. \& Turan, F. (2002). Türk çocuklarında üst dil becerilerinin gelişimi ve okuma ile ilişkisi. Türk Psikoloji Dergisi, 17 (50), 63-73.

Akbey, G. Ö. (2016). Down Sendromlu bireylerin akıcı okuma ve okuduğunu anlama ile fonolojik farkındalık düzeyleri arasındaki ilişki (Unpublished MA thesis). Anadolu University, Eskişehir.

Akoglu, G \& Turan, F. (2012). Eğitsel müdahale yaklaşımı olarak sesbilgisel farkındalık: zihinsel engelli çocuklarda okuma becerilerine etkileri. Hacettepe Üniversitesi Eğitim Fakültesi Dergisi, 42(42), 11-22.

Aktan, E. (1996). Çocuğun dil geliş̧iminde fonolojik duyarlılı̆̆ın (sesbirim duyarlılığı) karşılaş̧tırılmalı olarak incelenmesi (Unpublished MA thesis), Marmara Üniversitesi Sosyal Bilimler Enstitüsü, İstanbul.

Alderson, J. C. \& Hudson, R. (2012). The metalinguistic knowledge of undergraduate students of English language or linguistics. Language Awareness, 22(4), 320-337.

Ali, S. (2011). Critical language awareness in pedagogic context. English Language Teaching, 4(4), 2835

Alim, H. S. (2005). Critical language awareness in the US: Revisiting issues and revising pedagogies in a resegregated society. Educational Researcher, 34, 24-31.

Allor, J. H. (2002). The relationships of phonemic awareness and rapid naming to reading development. Learning Disability Quarterly, 25, 47-57.

Andrews, S. (1997). Metalinguistic awareness and teacher explanation. Language Awareness, 6(2), 161177.

Andrews, S. (2001). The language awareness of the L2 teacher: Its impact upon pedagogical practice. Language Awareness, 10(23), 28-35.

Andrews, S. (2007). "Researching and developing teacher language awareness: developments and future directions", In J. Cummins and C. Davidson (Eds.), International Handbook of English Language Teaching, New York: Springer. 
Andrews, S. (2008). "Teacher language awareness". In Encyclopedia of Language and Education, New York: Springer.

Anthony, J. L \& Francis, D. J. (2005). Development of phonological awareness. Current Directions in Psycological Science, 14(5), 255-259.

Aytas, G., \& Cecen, M. A. (2010). Ana dili eğitiminde dil bilgisi öğretiminin yeri ve önemi. Türklük Bilimi Araştırmaları, 27, 77-89.

Batur, Z. \& Beyret, T. N. (2015). Relationship between metalinguistic awareness skills and writing skills of middle school students. Electronic Turkish Studies, 10(15), 873-892.

Bednar, L. (1990). Enhancing metalinguistic awareness in the literature classroom: Two case studies. ERIC Document, ED 320150.

Berry, R. (2014). "Investigating language awareness: the role of terminology." A. Łyda and K. Szczes'niak (Eds.), Awareness in Action, Second Language Learning and Teaching, Switzerland: Springer International Publishing.

Bolitho, R., Carter, R., Hughes, R., Ivanic, R., Masuhara, H. and Tomlinson, B. (2003). Ten questions about language awareness. ELT Journal, 29, 68-72.

Borekci, M. (2009). Türkiye Türkçesinde yapt ve işlev bakımından sözcükler. Erzurum: Ofset Yay.

Buyukkantarcioglu, N. (2006).Toplumsal gerçeklik ve dil. İstanbul: Multilingual.

Buyukozturk, Ş., Kilic Cakmak, E., Akgun, Ö. E., Karadeniz, Ş. \& Demirel, F. (2014). Bilimsel araştırma yöntemleri. Ankara: Pegem Yayıncılık.

Byram, M. (2012) Language awareness and (critical) cultural awareness - relationships, comparisons and contrasts. Language Awareness, 21(1-2), 5-13.

Carter, R. (2003). Language awareness. ELT Journal, 57(1), 123-134.

Cazden, C. B. (1991). Metalinguistic awareness revisited: Its contribution to the child's appropriation of form. ERIC Document, ED 362066.

Cin Seker, Z. (2018). Sabahattin Ali'nin "Değirmen" adlı öyküsüne göstergebilimsel bir yaklaşım. Journal of International Social Research, 11(56), 32-38.

Cin Seker, Z. (2019). Göstergebilimsel metin çözümlemeye dayalı etkinliklerin ortaokul öğrencilerinin hikâye çözümleme becerilerine etkisi. Anemon Muş Alparslan Üniversitesi Sosyal Bilimler Dergisi, 7, 9-28.

Demir, C., \& Yapici, M. (2007). Ana dili olarak Türkçenin öğretimi ve sorunları. Sosyal Bilimler Dergisi, 9(2), 177-192.

Diniz Leal, M. C. (1998). Critical language awareness in the teaching of Portuguese. Language Awareness, 7(1), 23-34.

Dolunay, S. K. (2010). Dil bilgisi öğretiminin amacı ve önemi. Türklük Bilimi Araştırmaları, 27, 275 284.

Ekinci Celikpazu, E. (2019). Dilin temel işlevi ve Türkçenin yapısı açısından 2018 Türkçe Dersi Öğretim Programı'ndaki dil bilgisi kazanımlarının aşamalılığı. Erzincan Üniversitesi Ĕ̆itim Fakültesi Dergisi, 21(2), 107-125.

Ellis, E. M. (2012). Language awareness and its relevance to TESOL. University of Sydney Papers in TESOL, 7, 1-23. 
Emir, C., Girgin, M. C. \& Karasu, H. P. (2015). Kaynaştırma ve genel eğitim öğretmenlerinin sesbilgisel farkındalığa ilişkin öğretim etkinliklerini kullanımlarının incelenmesi. Journal of Education and Special Education Technology, 1(1), 15-33.

Erdoğan, Ö. (2009). İlköğretim birinci sını ögrrencilerinin fonolojik farkındalık becerileri ile okuma ve yazma becerileri arasındaki ilişki (Unpublished MA thesis). Hacettepe University, Ankara.

Erdoğan, Ö. (2011). İlk okuma yazma süreci için önemli bir beceri: Fonolojik farkındalık. Uludăg Üniversitesi Eğitim Fakültesi Dergisi, 24(1), 161-180.

Erkan Suel, E. (2011). Illköğretim 1.sınıf üstün ve normal zeka düzeyindeki öğrencilerin fonolojik farkındalı düzeylerinin okuma başarıları üzerine etkisinin karşılaştırılması (Unpublished MA thesis). İstanbul University, İstanbul.

Gibbs, S. (2004). Phonological awareness: An investigation into the developmental role of vocabulary and short-term memory. Educational Needs, 5(2), 62-67.

Gillon, G. (2004). Phonological awareness: From research to practice. New York: The Guilford Press.

Gillon, G. (2005). Phonological awareness: Effecting change through the integration of research findings. Language, Speech and Hearing Services in Schools, 36, 346-349.

Gokçe, K. (2006). Anasınıfina devam eden farklı sosyo-kültürel seviyedeki çocukların fonolojik duyarlılıklarının incelenmesi (Unpublished MA thesis). Hacettepe University, Ankara.

Gül, G. (2006). Hafif derecede zihinsel engelli çocukların okuma becerilerine sesbilgisel farkındalı eğitiminin etkisinin incelenmesi (Unpublished MA thesis), Hacettepe University, Ankara.

Guldenoglu, B., Kargin, T. \& Ergul, C. (2016). Sesbilgisel farkındalık becerilerinin okuma ve okuduğunu anlama üzerindeki etkisi: Boylamsal bir çalışma. İlkögretim Online, 15(1), 251-272.

Hamilton, M.E. \& Barton, D. (1980). A word is a word: Metalinguistic skills in adults of varying literacy levels. ERIC Document, ED 222859.

Harbon, L. (2007). Short-term international experiences and teacher language awareness. International Education Journal, 8(1), 229-243.

Iscan, A., Karagöz, B., \& Konyar, M. (2017). Cultural transfer and creating cultural awareness in teaching Turkish as a foreign language: A sample from Gaziosmanpasa University Tömer. Journal of Education and Practice, 8(9), 53-63.

Jackson, D. O. (2014). "Learner Differences in Metalinguistic Awareness: Exploring the Influence of Cognitive Abilities and Language Experience." Ryan T. Miller et al. (Eds). In Selected Proceedings of the 2012 Second Language Research Forum, (pp.211-226). Somerville, MA: Cascadilla Proceedings Project.

Jessner, U. (1999). Metalinguistic awareness in multilinguals: cognitive aspects of third language learning. Language Awareness, 8(3\&4), 201-209.

Johns, J. L. (1979). Relationships between metalinguistic awareness and reading achievement. ERIC Document, ED 136225.

Karaagac, G. (2013). Dil bilimi terimleri sözlüğü. Ankara: Türk Dil Kurumu Yayınları.

Karadag, O. \& Kurudayioglu, M. (2010). Türkçedeki kelime türetme özelliğinin ilköğretim ögrencilerinin yazılı anlatımlarına yansıması. TÜBAR-XXVII, 437-455. 
Karakas, O., Turkan, A. H., ve Ozdemir, Ş. (2013). Fen edebiyat ve eğitim fakültesi öğrencilerinin dil kirliliğine duyarlılığı üzerine bir araştırma: Afyonkarahisar örneği. Electronic Turkish Studies, 8(4), 927-937.

Karaman, G. (2006). Anasınıfina devam eden farklı sosyo-kültürel seviyedeki çocukların fonolojik duyarlllıklarının incelenmesi (Unpublished MA thesis). Hacettepe University, Ankara.

Karaman, G., \& Ustun, E. (2011). Anasınıfına devam eden çocukların fonolojik duyarlılıklarının bazı değişkenlere göre incelenmesi. Hacettepe Üniversitesi Eğitim Fakültesi Dergisi, 40, 267-278.

Kaya, D. (2010). Exploring teacher language awareness: an example study with prospective English teachers (Unpublished MA thesis). İstanbul University, İstanbul.

Ke, S. \& Xiao, F. (2015). Cross-linguistic transfer of morphological awareness between Chinese and English. Language Awareness, 24(4), 355-380.

Kilic, M., \& Akcay, A. (2011). Türkçe Öğretmen adaylarının görüşleri çerçevesinde dilbilgisi eğitimi. Sakarya University Journal of Education, 1(1), 26-31.

Kissling, E. M. \& O’Donnell, M. E. (2015). Increasing language awareness and self-efficacy of FL students using self-assessment and the ACTFL proficiency guidelines. Language Awareness, 24(4), 283-302.

Little, D. (1997). Language awareness and the autonomous language learner. Language Awareness, 6 (2/3): 93-104.

Mann, V. A., \& Joy, J. G. (2003). Phonological awarenesss, speech development and letter knowledge in preschool children. Annals of Dyslexia, 55, 149-173.

The Ministry of National Education. (2018). Türkçe dersi öğretim programı. Ankara: MEB Yayınları.

Mok, J. (2013). A case study of developing student-teachers' language awareness through online discussion forums. Language Awareness, 22(2), 161-175.

Oktay, A. \& Aktan, E. (2002). A cross-linguistic comparison of phonological awareness and word recognition in Turkish and English. International Journal of Early Years Education, 10(1), 37-48.

Onan, B. \& Ozcakmak, H. (2014). Türkçe deyimlerde dil farkındalığı ve işlevsel dil kullanımı. Ana Dili Eğitimi Dergisi, 2(1), 1-22.

Sayar, F., \& Turan, F. (2012). Okuma gelişiminde üst dil farkındalığı, sesbilgisel süreçler ve bellek süreçlerinin etkisi: Kısa süreli bellek ve çalışma belleği. Ankara Üniversitesi Eğitim Bilimleri Fakültesi Özel Eğitim Dergisi, 13(2), 49-67.

Smith, M. S. (2008). Morphological and syntactic awareness in foreign/second language learning. Encyclopedia of Language and Education, 1935-1947.

Tomlinson, B. \& Masuhara, H. (2004). Developing cultural awareness. Modern English Teacher, 13(1), $5-11$.

Tucker, E. S. (1976). Effects of written language and metalinguistic awareness on language acquisition from 5-12. ERIC Document, ED 137800.

Turan, F. \& Akoglu, G. (2014). Okul öncesi dönemde ev okuryazarlık ortamı ve fonolojik farkındalık becerileri. Hacettepe Üniversitesi Ĕ̌itim Fakültesi Dergisi, 29(3), 153-166.

Turan, F. \& Gul, G. (2008). Early precurser of reading: Acquisition of phonological awareness skills. Educational Sciences: Theory and Practice, 8(1), 265-284. 
Turan, F. \& Akoglu, G. (2011). Okul öncesi dönemde sesbilgisel farkındalık eğitimi. Eğitim ve Bilim Dergisi, 36(161), 64-75.

Van Lier, L. (1991). Language awareness: The common ground between linguist and language teacher. Georgetown University Round Table 1991: 528-46. Washington, DC: Georgetown University Press.

Varisoglu, B. (2018). Turkish Metalinguistic Awareness Scale: A validity and reliability study. Universal Journal of Educational Research, 6(4), 691-700.

Varisoglu, M. C. (2018). Türk dili ve edebiyatı bölümü öğrencilerinin klasik Türk edebiyatı derslerine ilişkin görüşleri. Sosyal Bilimler Araştırmaları Dergisi, 13(2), 283-304.

White, J. \& Kennedy, S. (2014). Language awareness: a world of perspectives. Language Awareness, 23(1-2), 1-2.

Wright, M. \& Bolitho, R. (1993). Language awareness: A missing link in language teacher education. ELT Journal, 47(4), 292-304.

Yucel, D. (2009). Sesbilgisel farkındalık (Fonolojik farkındalık) eğitiminin okuma sorunu olan çocuklar üzerindeki etkisinin incelenmesi (Unpublished MA thesis). Hacettepe University, Ankara.

Zhang, Y. \& Li, R. (2016). The role of morphological awareness in the incidental learning of Chinese characters among CSL learners. Language Awareness, 25(3), 179-196.

Zheng, Y. (2014). The fluctuating development of cross-linguistic semantic awareness: A longitudinal multiple-case study, Language Awareness, 23(4), 369-388.

Zipke, M. (2008). Teaching metalinguistic awareness and reading comprehension with riddles. Reading Teacher, 62(2), 128-137. 


\section{Öğretmen adaylarının Türkçe üst dilsel farkındalıklarının incelenmesi}

\section{$\ddot{O} \mathbf{z}$}

Dil farkındalı̆̆ı, dili bilme ve uygulamayla ilgili bilinçli çabaların bütünüdür. Üst dilsel farkındalık ise dilin bilgisinin ve dili kullanma becerisinin yanında dille ilgili sosyal, kültürel, tarihsel ve ideolojik yönlerin bir bütün olarak keşfedilmesidir. Bu çalışmanın amacı ana dilleri Türkçe olan ve İngilizce, Almanca, Türkçe ve Türk Dili ve Edebiyatı bölümlerinde okuyan öğretmen adaylarının Türkçe üst dilsel farkındalıklarını cinsiyet ve bölüm değişkenleri açısından incelemektir. Araştırmada nicel araştırma desenlerinden olan betimsel tarama modeli kullanılmıştır. Araştırmada evren olarak Atatürk Üniversitesi Kâzım Karabekir Eğitim Fakültesi İngilizce, Türkçe, Almanca ve Türk Dili ve Edebiyatı Eğitimi bölümlerinde okuyan öğretmen adayları seçilmiştir. Örneklem ise bu evrenden amaçlı örnekleme tekniğiyle belirlenen son sınıf öğrencilerinden oluşmaktadır ( $\mathrm{N}=164)$. Çalışmanın verileri B. Varışoğlu (2018) tarafindan geliştirilen “Türkçe Üst Dilsel Farkındalık Ölçeği” ile toplanmıştır. Verilerin analizinde betimsel analiz tekniklerinden yararlanılmıștır. Sonuç olarak öğretmen adaylarının Türkçe üst dilsel farkındalıklarının yüksek olduğu; en düşük farkındalıklarının şekil bilgisel farkındalık alt boyutunda, en yüksek farkındalıklarının ise kültürel farkındalık alt boyutunda olduğu anlaşılmıştır. Cinsiyet değişkenine göre kız öğretmen adaylarının lehine anlamlı bir farklılığın olduğu, ancak bölüm değişkeninin öğretmen adaylarının Türkçe üst dilsel farkındalıkları üzerinde anlamlı bir etkiye sahip olmadığı görülmüştür.

Anahtar sözcükler: dil; dil eğitimi; dil farkındalığı; Türkçe üst dilsel farkındalık; öğretmen adayları

\section{AUTHOR BIODATA}

İzzet Şeref received his doctorate degree in Atatürk University, Faculty of Education, Department of Turkish Language Education. Has research fields include instruction of Turkish as a native language and as a foreign language. Currently, he works as an assistant professor at Tokat Gaziosmanpaşa University, Faculty of Education, Department of Turkish Language Education.

Behice Varışoğlu received her doctorate degree in Atatürk University, Faculty of Education, Department of Turkish Language Education. Her research fields include instruction of Turkish as a native language and as a foreign language. Currently, she works as an associate professor at Tokat Gaziosmanpaşa University, Faculty of Education, Department of Turkish Language Education. 